\title{
One Problem, Different Manifestation: Distribution Woes At HDFC Life And SBI Life
}

\author{
Tanmay Pant, Sandeep Arya
}

\begin{abstract}
Life insurance distribution in India, like elsewhere, is in a transitory phase. Technological advancements and an untapped market have opened up new vistas in the field. Customer offerings through multiple touch-points seem to be the mantra. While a multi-channel strategy does offer the outreach, there are a number of issues, including, channel conflict, channel cannibalization and channel misalignment, which act as a dampener to such a strategy. The other question is that of finding an optimum distribution mix. We, by virtue of this paper, attempt to delineate the aforesaid, highlighting the manifestation of the same problem of distribution, albeit differently, rather contrastingly - concurrently suggesting the solutions - through two similar bank led (large bank as group company / bank promoted) companies, HDFC Life and SBI Life. Distribution woes have resulted in an uncertain distribution landscape with no clear pattern in sight. Industry numbers show a shrinking agency, a robust bancassurance and a rising online channel. But the pattern is all lopsided in HDFC Life and SBI Life. How to balance the distribution mix, then? Does that mean doing away with the not so hot agency channel? Or does preserving agency still make sense? Or fortifying the banca further is the need of the hour? Or, can the currently hot direct / online channel be pursued vehemently? The implications of such distribution patterns are immense for an industry trying to find a way out of the muddle.
\end{abstract}

Keywords - uncertain distribution landscape, balance, lopsided, distribution mix.

\section{INTRODUCTION:}

Two of the most important metrics for insurance - the penetration and density - showcase India in a poor light. India, despite a market characterised by a rising middle class, has failed to cash in (Table $1 \& 2$ ) on the immense potential of life insurance business.

Table 1: Life Insurance Penetration

\begin{tabular}{|l|r|r|r|r|r|}
\hline Countries & $\mathbf{2 0 1 3}$ & $\mathbf{2 0 1 4}$ & $\mathbf{2 0 1 5}$ & $\mathbf{2 0 1 6}$ & $\mathbf{2 0 1 7}$ \\
\hline & \multicolumn{5}{|c|}{ Life Insurance Penetration } \\
\hline Australia & 3.00 & 3.80 & 3.50 & 2.99 & 2.33 \\
\hline Brazil & 2.20 & 2.10 & 2.10 & 2.28 & 2.28 \\
\hline France & 5.70 & 5.90 & 6.20 & 6.06 & 5.77 \\
\hline Germany & 3.10 & 3.10 & 2.90 & 2.75 & 2.63 \\
\hline Russia & 0.10 & 0.20 & 0.20 & 0.25 & 0.36 \\
\hline
\end{tabular}

Revised Manuscript Received on November 11, 2019.

* Corresponding Author

Tanmay Pant, Research Scholar, Dept. of HSS, JUET, Guna (M.P.) \& Assistant Professor, GIBS, Rohini, Delhi. India.

\begin{tabular}{|l|r|r|r|r|r|} 
South Africa & 12.7 & 11.4 & 12.00 & 11.52 & 11.02 \\
\hline Switzerland & 5.30 & 5.10 & 5.10 & 4.72 & 4.41 \\
\hline $\begin{array}{l}\text { United } \\
\text { Kingdom }\end{array}$ & 8.80 & 8.00 & 7.50 & 7.58 & 7.22 \\
\hline United States & 3.20 & 3.00 & 3.10 & 3.02 & 2.82 \\
\hline & & & & & \\
\hline $\begin{array}{l}\text { Asian } \\
\text { Countries }\end{array}$ & & & & & \\
\hline Hong Kong & 11.7 & 12.7 & 13.30 & 16.20 & 14.58 \\
\hline India\# & $\mathbf{3 . 1 0}$ & $\mathbf{2 . 6 0}$ & $\mathbf{2 . 7 0}$ & $\mathbf{2 . 7 2}$ & $\mathbf{2 . 7 6}$ \\
\hline Japan\# & 8.80 & 8.40 & 8.30 & 7.15 & 6.26 \\
\hline Malaysia\# & 3.20 & 3.10 & 3.40 & 3.15 & 3.32 \\
\hline Pakistan & & & & & \\
\hline PR China & 0.50 & 0.50 & 0.50 & 0.63 & 0.60 \\
\hline Singapore & 4.60 & 1.70 & 2.00 & 2.34 & 2.68 \\
\hline South Korea\# & 7.50 & 5.00 & 5.60 & 5.48 & 6.64 \\
\hline Sri Lanka & 0.50 & 0.50 & 0.50 & 0.52 & 0.54 \\
\hline Taiwan & 14.5 & 15.6 & 15.70 & 16.65 & 17.89 \\
\hline Thailand & 3.80 & 3.60 & 3.70 & 3.72 & 3.59 \\
\hline World & $\mathbf{3 . 5 0}$ & $\mathbf{3 . 4 0}$ & $\mathbf{3 . 5 0}$ & $\mathbf{3 . 4 7}$ & $\mathbf{3 . 3 3}$ \\
\hline
\end{tabular}

Source: Swiss Re, Sigma various volumes; data relates to Calendar year;

* Insurance penetration is measured as ratio of premium to GDP;

\# data relates to financial year.

Table 2: Life Insurance Density

\begin{tabular}{|l|r|r|r|r|r|}
\hline \multirow{2}{*}{$\begin{array}{c}\text { Countrie } \\
\text { s }\end{array}$} & $\mathbf{2 0 1 3}$ & $\mathbf{2 0 1 4}$ & $\mathbf{2 0 1 5}$ & $\mathbf{2 0 1 6}$ & $\mathbf{2 0 1 7}$ \\
\cline { 2 - 6 } Life Insurance Density \\
\hline Australia & 2056.0 & 2382.0 & 1830.0 & 1558.5 & 1304 \\
\hline Brazil & 246.0 & 222.0 & 178.0 & 195.5 & 224 \\
\hline France & 2391.0 & 2552.0 & 2263.0 & 2227.7 & 2222 \\
\hline Germany & 1392.0 & 1437.0 & 1181.0 & 1150.6 & 1169 \\
\hline Russia & 19.0 & 20.0 & 15.0 & 22.4 & 39.0 \\
\hline $\begin{array}{l}\text { South } \\
\text { Africa }\end{array}$ & 844.0 & 748.0 & 688.0 & 615.8 & 674.0 \\
\hline $\begin{array}{l}\text { Switzerla } \\
\text { nd }\end{array}$ & 4211.0 & 4391.0 & 4079.0 & 3700.3 & 3522 \\
\hline $\begin{array}{l}\text { United } \\
\text { Kingdom }\end{array}$ & 3474.0 & 3638.0 & 3292.0 & 3033.2 & 2873 \\
\hline $\begin{array}{l}\text { United } \\
\text { States }\end{array}$ & 1684.0 & 1657.0 & 1719.0 & 1724.9 & 1674 \\
\hline & & & & & \\
\hline
\end{tabular}




\begin{tabular}{|l|r|r|r|r|r|}
$\begin{array}{l}\text { Asian } \\
\text { Countrie } \\
\text { S }\end{array}$ & & & & & \\
\hline $\begin{array}{l}\text { Hong } \\
\text { Kong }\end{array}$ & 4445.0 & 5071.0 & 5655.0 & 7065.6 & 6756 \\
\hline India\# & $\mathbf{4 1 . 0}$ & $\mathbf{4 4 . 0}$ & $\mathbf{4 3 . 0}$ & $\mathbf{4 6 . 5}$ & $\mathbf{5 5 . 0}$ \\
\hline Japan\# & 3346.0 & 2926.0 & 2717.0 & 2803.4 & 2411 \\
\hline $\begin{array}{l}\text { Malaysia } \\
\text { \# }\end{array}$ & 341.0 & 338.0 & 316.0 & 298.3 & 339.0 \\
\hline Pakistan & 6.0 & 7.0 & 8.0 & 9.2 & 9.0 \\
\hline PR China & 110.0 & 127.0 & 153.0 & 189.9 & 225.0 \\
\hline $\begin{array}{l}\text { Singapor } \\
\text { e }\end{array}$ & 2388.0 & 2840.0 & 2932.0 & 2894.5 & 3835 \\
\hline $\begin{array}{l}\text { South } \\
\text { Korea\# }\end{array}$ & 1816.0 & 2014.0 & 1940.0 & 2049.6 & 1999 \\
\hline $\begin{array}{l}\text { Sri } \\
\text { Lanka }\end{array}$ & 16.0 & 17.0 & 19.0 & 21.2 & 22.0 \\
\hline Taiwan & 3204.0 & 3371.0 & 3397.0 & 3598.7 & 4195 \\
\hline Thailand & 214.0 & 198.0 & 215.0 & 222.0 & 237.0 \\
\hline World & $\mathbf{3 6 6 . 0}$ & $\mathbf{3 6 8 . 0}$ & $\mathbf{3 4 6 . 0}$ & $\mathbf{3 5 3 . 0}$ & $\mathbf{3 5 3}$ \\
\hline Sorce: Sw & & & & \\
\hline
\end{tabular}

Source: Swiss Re, Sigma various volumes; Data relates to Calendar year.

* Insurance density is measured as ratio of premium (in US Ddffldiffetinsatalnce was intriguing, distribution takes the piè. As population.

\# data relates to financial year .

Tables $1 \& 2$ indicate that India compares unfavaorably with average figures worldwide - and even in Asia - with respect to the penetration and density numbers. A pertinent question then arises about what could have led to such a dismal show? Factors could be awareness, products, distribution etc. With increased government support post reforms and the access to technology, lack of awareness to the extent of such poor numbers is ruled out. Almost all companies have a well rounded product basket and more or less all companies sport the same products today. Strikingly then, why is that some companies do well with the same products while others don't? What the failing companies have not done well and which we, the authors, consider the missing piece of the puzzle, is the distribution aspect. Mehta (2015) opines that distribution is an aspect that is slowly but surely defining the companies. But hang on, even the companies doing well on this front, have not zeroed-in on an optimum distribution mix and are rallied solely by one channel or the at the most by two channels. Upfront, we would like to clarify that by a deficient distribution system we mean both the deficiency in distribution outreach as well as deficiency in the distribution channel balance mix. The aforesaid, though, is not an easy proposition especially when technology has impacted every sphere like never before. Theerefore this case study, most probably, could not have come at a better time than this. Technology, in altogether different avatar of a 'coming up the rungs' distribution channel (online) and also as a support to the established channels, has changed the distribution scenario in life insurance.

\section{Distribution: What's so special about it?}

It is said that out of the four P's of marketing, if there is one $\mathrm{P}$ that is most inimitable then it is the Place or Distribution. A look at the Indian life insurance distribution space would make it amply clear that while new and innovative channels have emerged on the scene, the bulk of sales is carried through three or the at the most four channels, namely the agents, the banks, the brokers and the corporate agents other than the banks. On the back of rising technological advancements, the online channel is steadily but surely making a name for itself. In fact, technology as an all pervasive medium, has been largely responsible for the apparent that the Indian market is served through multiple touch-points by a large nmber of channels, many of which are as different as chalk and cheese. In context of the above, when such pivotal bases are covered, it is even more intriguing to know that the life insurance penetration and density numbers are awful (Table $1 \& 2$ ). The case in point of this study - two similar bank led / promoted companies furthers the mystique. Yet another strand of research similar non bank promoted companies; bank promoted companies vs. non bank promoted companies - would ( as a future research) open up the pandora's box as this unchartered territory gets explored. All this has a strong bearing on the distribution templates for the industry.

stated above, the companies differ in their origin and ownership structures (some bank promoted, others not) and distribution within and across these companies has, in the last decade varied greatly, and therefore it seems very logical to unearth the probable reasons for under performance of distribution as far as the penetration of life insurance and its density is concerned. A recent study (Cognizant report, 2014) talks about the disruptions in distribution patterns of life insurance companies and while acknowledging that the counter from the companies is a multi-channel structure, it forewarns them to gear up for continuous disruptions and thus keep on tweaking the distribution structure. The study also argues that companies remain ahead of the curve (FOD, future of distribution) so as to stand out in the crowd and simultaneously work on balancing the distribution mix.

It further goes on to inform that a unified view of the three the company, the channel and the customer would go a long way in addressing the distribution woes and in turn, lead to decent penetration and density numbers. Uptill now, we have highlighted the distribution problem prevalent in Indian companies which remains a puzzle at best but, as stated earlier, the puzzle is even more pronounced when we, by virtue of this paper, present a contrasting view of the same distribution problem in top two typical bank led / promoted companies (HDFC Life \& SBI Life) - which should ideally leverage their large banking strength to life insurance sales at a time when companies are grappling with designing an optimum distribution mix.

\section{The distribution landscape in India:}

Two channels, Agency and Bancassurance have, since the last decade and a half, been the top premium earners, garnering as much as $85 \%$ of the new incoming premium. The direct business (including online), brokers and others account for the rest. As mentioned earlier, the online channel has shown promise but spread of new and innovative channels. It is, therefore, 
not to an extent to be called as the channel of choice and in all probability will continue to be promising in the foreseeable future. The industry has over the years seen a tectonic shift in bancassurance emerging as a premier channel for private players in the last 5-6 years, overpowering the traditional agency. The fact that the agency still continues to hold forteeven with sliding numbers - in some companies, has to do with the 'personal involvement' in buying life insurance, an aspect which will always keep the agency relevant. So while the common refrain is to tow the industry line and go the bancassurance way, some firms have preserved the agency numbers. Adding spice to the mix is the fact that there already are some firms which have derived lucrative business through the online channel and looking purely from a cost perspective those firms are batting for it as the soon to be channel of choice. A relevant question then arises: how to set a priority for channel selection? How to balance the distribution mix? It is this aspect of distribution which has companies in a quandary. Agency just cannot be dispensed with overnight; bancassurance can just not be rubbished at a time when it is hot property; online has shown enough promise to be touted as the future. What are the companies left with then? Each one of the above channels come with certain merits and demerits and it is indeed a challenge, therefore in arriving at an all elusive optimum mix when headwinds of continuous disruptions stare at the face. It presents the companies with the dilemma of choosing and picking amongst the channels. Specifically then, an answer is attempted through two more or less same type of firms - at least by the presence of large banks in the group - in this study. The study comprises of two typical large bank dominated group companies.

\section{LITERATURE REVIEW:}

Amongst the many channels which operate today, concurrently so, the agents, bancassurance and much recently, the direct channel (prominently online) have grabbed a major chunk of business. Broker, a channel to reckon with a few years back has lost some shine and is not in the reckoning of late. Hence, the literature review that ensues will mainly cater to the top three (agents, bancassurance and online) along with a coverage of the multi-channel mix.

Mirroring what happened elsewhere, India has seen - in a departure from earlier times - bancassurance emerging as the favoured channel in place of agency, especially for private companies. LIC as the flag bearer of Indian life insurance for a considerable period, had an agent distribution model in place, which remained the norm even after privatization until innovations in the channel space by private players brought new channels including bancassurance to the forefront during the early years of the new millennium.

Earlier it was thought that a large sales force could maximize the sales and hence a flourishing agency (Finsinger and Schmidt, 1993). Agency, in spite of the other channels making a mark and change in commission structure and other requirements, still continue to be one of the main channels. Brostoff (2001), the national underwriter, reported the survey of four associations which revealed that the agents would continue to remain as a premier channel. A 1995 study of Posey and Yavas suggested that took note of the fact that earlier studies claimed that independent agency has a higher cost than a direct writer system. Inferring thus, they (Posey \& Yavas) were of the view that going by those studies the inherent competition in the insurance market should have removed the independent agency system. Yet as shown by them (Posey \& Yavas) the independent agency continues to coexist along with the direct writer system.

At a time when the agency was losing its shine - while still continuing to be an important channel - bancassurance came up the rungs. Studies of Felgren (1985) and Todd and Murray (1988) reveal that the usage of bank branches curtail the expenses of selling and delivering products of insurance, unlike the traditional agency systems. Claessens (2003), in sync with Benoist (2002) have contributed to the literature involving financial collaborations resulting in integrated distribution of products and services.

Following the west, the Asian region, too stood witness to the growth of bancassurance - somewhere as a forced change, somewhere accidently. Taiwan took to bancassurance because of the over banking problem where excess capacity of banks had to utilised. In India, bancassurance growth has been steady and it has become the channel that drives business for private companies (HDFC Annual Report, 2019).

The other important channel to have made a mark is the direct / internet / online channel. Labelled as a future channel of much promise, it currently operates as one offering simple and cheaper insurance products. The spread of the internet, of late, has sprung up the growth of electronic channels and markets as also electronic intermediaries. These are the platforms for multiple transactions involving the buyers and the sellers (Malone et al., 1987; Sarkar et al., 1995). Agent led distribution through channels like the direct writers and independent agents was mostly the norm - which still continues to be in some economies - before the spread of the internet. It is only of late that the direct channel has got wider recognition. It was expected to impact negatively on the traditional agency but even today there is not a distinct preference for it, although it is gaining ground (Trembly, 2001).

It is an established fact that multi channel distribution is one solution towards gaining sound penetration and density numbers. However, the reason for coexistence of multiple channels is the difference in quality of products as also the imperfections in the insurance markets. Difference in product quality implies that higher / lower price of insurance products dictates the type of channel catering to takers of those products. Barrese et al. (1995), opine that the much in demand independent agency has something to do with the larger complexity of commercial insurance than personal insurance. On similar lines, Query and Hoyt (2002) support the differential services. Another study of note, Regan (1997), taking the cost perspective of transactions into account, concluded that complex products warrant independent agency as the 
channel of approach while standardized products call for using the exclusive agents. The study of Mayers and Smith (1981) reveal that as the insurance products gets costly and complex, distribution via an independent agency seems to be the best choice.

In stark contrast to most studies, a recent Cognizant (2014) study reveals that as a telltale sign, the category of insurance products will be influenced by the channels. As with everything, the demerit of having a multi distribution structure is the cost disadvantages which happen when high costs are incurred for establishing an additional distribution channel. Easingwood and Storey (1996) are of the view that when there are high coordination costs - between the channels - because of having more channels, disruptions are bound to occur in a company. Moreover, redirection of turnover and profits from one channel to the other (channel cannibalization) is also a distinct disadvantage of having a multi distribution regime (Dzienziol et. al, 2002).

Thus far much has been said of the three channels concerned; however the much unanswered question - how to strike a balance in distribution leading to an optimum mix? - seeks a suitable solution. And, in terms of efficiency of channels - an area of recent research activity - which channels to be given more weightage? While there are studies in Taiwan regarding the efficiency of channels for life insurance companies, the same cannot act as a basis for studies in different countries as the regulatory mechanisms differ.

However, one should not lose sight of the fact that those studies do offer some vital insights. Nevertheless, the study of Chen \& Chang (2010) found revealed that vis-à-vis a non direct channel strategy, a direct channel strategy is more efficient. In another study by Pang \& Fan (2011), traditional channel efficiency was found more than that of a bancassurance channel. The above fact is in contrast to bancassurance being a favoured channel. Therefore, from the lens of efficiency, recent times have seen studies centring around finding the most profitable channels. An earlier pioneering study of Joskow (1973) focussed on property and liability insurance industry in the United States concluded that insurers employing direct writers had $11 \%$ lower expense ratios than insurers using independent agents.

Some later works (Cummins \& Van Derhei, 1979; Barrese \& Nelson, 1992) echoed Joskow's. Regan (1999), in a larger study, states that the cost advantages of direct writers are different for different insurance lines. Berger, Cummins and Weiss (1997) state that insurers employing direct writers are much more efficient than those having independent agents. Regan and Tzeng (1999) state that ownership form is closely related to the distribution system. Williamson (1981) and Klein, Crawford \& Alchian (1978) found that direct channels were more effective either when a specialised knowledge of products was required or when the sales relationship involved difficult tasks. Talking from the perspective of an agent oriented versus a broker oriented insurer, Baranoff et. al (2000) state that the former will have less expenses because they have a single distribution system.

The exclusive agent for a long time, until recently, was the most favoured channel recently, but bancassurance stole the show, first, and now the multi-channel (including agents, brokers, corporate agents, banks, direct etc.) hold sway. Marcel \& Doyle (1979) opine that with a continuously changing landscape making technology all pervasive, the insurance companies are looking at a combination of direct, agency and broker channels. While multi-distribution as of now seems to be an answer to the challenges, it is still not clear if it can cater to customers in different segments, primarily because of the inherent problem of channel conflict in such a structure (Webb, 2002). Additionally, pricing policy, for different distribution channel strategies is a challenge (Tang \& Xing, 2001)

In the Indian context no study, Sinha's (2013) work aside, has no study has delved deeper into understanding the distribution trends of companies. The study of Sinha (2013) with respect to distribution of the leading private players from 2005-06 to 2009-10, captures the channel trends of these players on the basis of premium generated and policies sold through channels like the agents, corporate agents (banks) and direct (online). The study acknowledges the evolution of the distribution landscape and stresses that multi distribution was imminent. A point of note is the fact that at the time of Sinha's (2013) study (period from 2005-06 to 2009-10) the balance of distribution was very much in favour of agency. Changing times post the aforementioned period (the last decade or so) have seen a tectonic shift - in the balance of distribution mix - becoming loaded in favour of bancassurance (for private players). Another study of note is Lakshmikutty \& Sridaran (2005) wherein described the state of various distribution channels of the time while highlighting the emergence of some new channels. Sharma \& Saxena (2009) while discussing about the changes in the distribution have stressed the absence of channels designed for the rural market and highlighted the significance of a multi distribution structure. One study of Tone \& Sahoo (2005) has analysed the cost efficiency analysis of the only public company, the Life Insurance Corporation (LIC) of India.

None of the aforementioned studies, however, have attempted to study the anomalies in the distribution mix of two similar bank led / promoted companies at a time when they are faced with the onerous task of balancing the distribution mix. Filling a sort of gap, we offer our contribution to literature by exploring the contrast in the distribution set ups of two similar bank aided companies HDFC Life led by the largest private sector bank, HDFC and SBI Life, led by the largest public sector bank, SBI) life insurance firms in India - as also the implications of the same.

\section{The distribution trend of the industry (private players):}

At the outset, it is imperative to interpret the premium numbers put up by the agency, the banca and the online channel over the last five-six years:

Exhibit 1 shows industry distribution trend for private companies for the last five years . Agency numbers have gone down by $10 \%$ and have 
been going downhill year after year. The last figure for 2018-19 stands at 26\%. During the same period, bancassurance numbers show an upward movement of $7 \%$. The numbers for the last three years are equal at $54 \%$ including the final figure for 2018-19. The online channel, rising steadily, capped off at $14 \%$ for $2018-19$, a jump of $5 \%$ from the low of $9 \%$ in 2014-15. An important point emphasized all through the paper and to be kept in mind is that with the addition of LIC to industry numbers would tilt the balance in favor of the agency as LIC thrives on business numbers through the agents. To drive through our point i.e. highlighting the distribution contrasts for two bank led firms in the private sector, this study makes use of data only for such firms.

\section{Exhibit 1: Distribution pattern for private players}

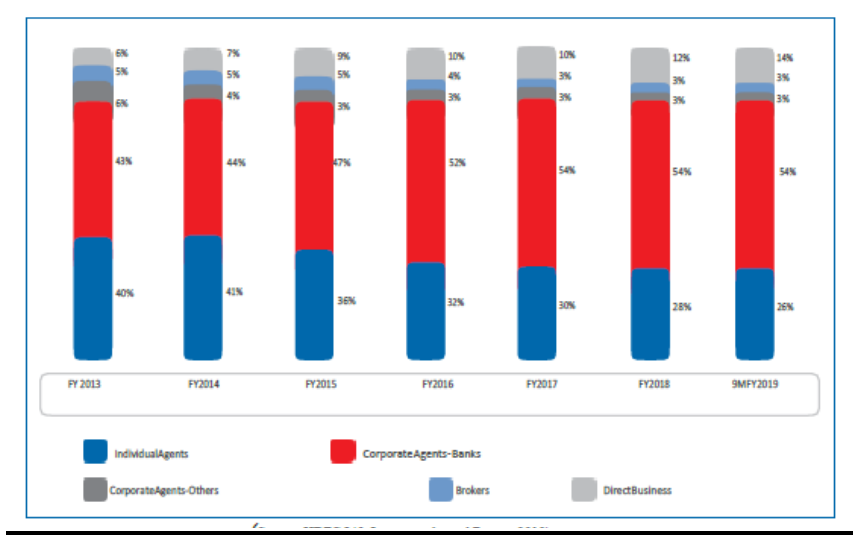

(Source: HDFC Life Insurance Annual Report, 2019)

Tables $3 \& 4$ and Exhibits $2 \& 3$ reveal the distribution trends (premium numbers) for the agency, the banca and the direct channel over the last five years for HDFC Life and SBI Life. The comparison of the said numbers with the corresponding industry trend for the channels (Exhibit 1) would give significant details about the nuances of the distribution mix of aforementioned firms, each of which is unique in their own right.

Table 3:Channel premium numbers for HDFC Life:

\begin{tabular}{|c|c|c|c|}
\hline $\begin{array}{c}\text { HDFC } \\
\text { LIFE }\end{array}$ & AGENT & BANK & $\begin{array}{c}\text { DIRECT / } \\
\text { ONLINE }\end{array}$ \\
\hline $2014-15$ & $16.50 \%$ & $67 \%$ & $10 \%$ \\
\hline $2015-16$ & $13.40 \%$ & $68 \%$ & $12 \%$ \\
\hline $2016-17$ & $15.40 \%$ & $61 \%$ & $15 \%$ \\
\hline $2017-18$ & $13.00 \%$ & $58 \%$ & $19 \%$ \\
\hline $2018-19$ & $13.70 \%$ & $49 \%$ & $31 \%$ \\
\hline
\end{tabular}

(Source: Compiled by the author through the data from HDFC Life annual reports)

Exhibit 2: Channel business numbers (premium) for HDFC Life:

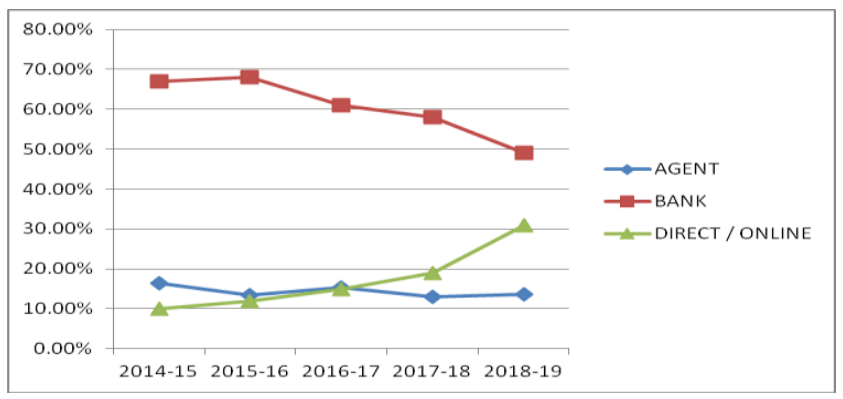

(Source: Compiled by the author through the data from HDFC Life annual reports)

HDFC Life: An overdose of bancassurance, a feeble agency and an ascending online

HDFC Life is premier life insurance company in India and is a joint venture between one of the prominent finfcial institutions, HDFC Ltd and Standard Life Aberdeen, a global investment company. Established in 2000, HDFC Life Insurance Company Limited (Formerly HDFC Standard Life Insurance Company Limited) is a reputed operator providing long-term life insurance solutions, covering customer needs like health, savings, pension and protection. As it stood on March $31^{\text {st }}, 2019$, the company has a host of products individual and group, numbering 38 and 11 respectively along with optional rider benefits (numbering 8), thereby catering to a broad spectrum of customer needs.

On the distribution front, HDFC Life has never been an agent centric firm. Rather, by fortifying bancassurance over the years - in the process living up to its billing as a robust bank led firm - through tie-ups with a plethora of banks and other partners, it has leveraged the captive base of such key partners. In doing so, HDFC Life continues have a pan India presence with 412 branches along with other touch-points. A varied partner group comprising 265 banca allies including Small Finance Banks (SFB's), Non-Banking Financial Companies (NBFC's) and Micro Finance Institutions (MFIs) in addition to 39 partnerships in the non-traditional ecosystem, has strengthened HDFC Life's presence. Adding to its formidable distribution is the robust base of financial consultants.

What is baffling is that HDFC Life ever since inception has for some not so obvious reasons - inherent nature of life insurance selling favours a reasonable agency even if you are a strong bank led firm - emphasized so much on bancassurance that except the last fiscal (2018-19), it has overtaken the industry numbers for private players. The agency numbers - which were anyway behind the industry have further moved southwards or have, at best, matched numbers of the previous fiscal years. Online channel has been growing steadily over the last five years and is poised to make further inroads in the coming years.

\section{The problem for HDFC Life: Emergence of a new} confusing distribution pattern

While the lack of a substantial agency at HDFC Life is well documented and did hurt the firm somewhere, the business numbers from bancassurance does validate a bank reliant 
strategy. The fact that life insurance is a product which is unsought and complex should not go amiss while promoting it. Related therefore, the element of personal interaction can never go away, thereby indicating that the agency should be persisted with. So while a reduced agency is a matter of concern, the bancassurance numbers - the much touted strength of the firm - for the last few years have also been below the industry trend (sans LIC). As a dark horse, out of the blue has emerged the direct channel (mailnly online), rising consistently; growing by a staggering $12 \%$ last year and much is talked about its potential. One fact that should not go amiss is that the rise of the online does in no way imply that large premium policies are also sold through it. Currently the channel operates on volume, selling simple policies which are cheaper.

That online would one day become the most preferred channel is no big surprise but the question is when that would happen. The probable answer lies in an auto-correction happening with the upcoming generation that would result in its consolidation when bucking the current trend, even big ticket size policies would sell through it. The dilemma starts thus for HDFC Life. What is left with HDFC Life until online becomes the go to channel for buying all types of life insurance? Do away with the agency, ignore the banca? Or bet big on the online channel judging its performance in the last fiscal even when currently it is at the most a channel selling small and simple policies? How does HDFC Life balance its distribution structure? While multi-channel mix is the buzz word, HDFC Life's channel mix seems lopsided and defies logic. During the course of the study we would seek some solutions, honestly.

Table 4: SBI Life channel business numbers (premium):

\begin{tabular}{|c|c|c|c|}
\hline SBI LIFE & AGENT & BANK & $\begin{array}{c}\text { OTHERS / DIRECT } \\
\text { / ONLINE }\end{array}$ \\
\hline $2014-15$ & $45.80 \%$ & $51.80 \%$ & $2.50 \%$ \\
\hline $2015-16$ & $37.78 \%$ & $60.74 \%$ & $1.48 \%$ \\
\hline $2016-17$ & $34.08 \%$ & $64.71 \%$ & $1.21 \%$ \\
\hline $2017-18$ & $31.23 \%$ & $67.43 \%$ & $1.34 \%$ \\
\hline $2018-19$ & $29.65 \%$ & $68.91 \%$ & $1.44 \%$ \\
\hline
\end{tabular}

(Source: Compiled by the author through the data from SBI Life annual reports)

\section{Exhibit 3: Channel premium numbers of SBI Life:}

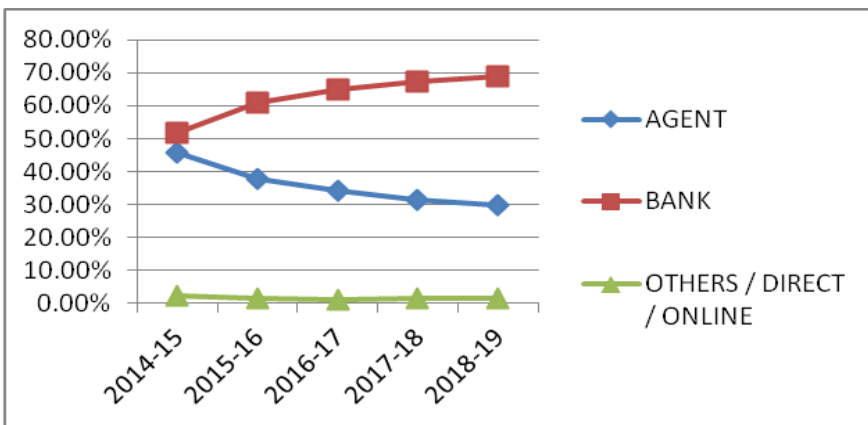

(Source: Compiled by the author through the data from SBI Life annual reports)
SBI Life: Formidable bancassurance, an above industry agency and subdued online

The largest bank of the country, State Bank of India joined hands with BNP Paribas Cardif - having its origin in France as a french financial services and multinational banking firm globally headquartered in Paris - to form SBI Life Insurance. The ownership stake of the SBI and BNP Paribas Cardif is is $62.1 \%$ and $22 \%$ respectively of the total capital. The remaining stake to the tune of $1.95 \%$ each of the total capital is shared by Value Line Pte. Ltd. and MacRitchie Investments Pte. Ltd., holding while the remaining $12 \%$ is Public. Having an authorized capital of Rs.20 billion (US\$290 million) and Rs.10 billion (US\$140 million) paid up capital, SBI Life, today counts as one of the premier life insurance firms in India.

Having a robust bancassurance structure in place - on expected lines from the company led by the largest bank, SBI - ever since inception in 2001, SBI Life has, for the past decade or so built a strong agency as well to complement the banking strength. Such has been the agency growth that SBI Life's numbers have, all through the last five years, been ahead of the industry agency numbers. Bucking the industry trend, though, is the online channel which has seen a degrowth in the last five years.

\section{The Problem for SBI Life: A distribution pattern both mirroring and defying industry trends}

Unlike HDFC Life, SBI Life has all through the last five years or so been ahead of the industry in agency numbers (premium through agency). What the agency numbers for the last five years tell is a story of the transformation SBI Life has undergone - since its inception in 2001 - from being a bancassurance dominated company - which it still is by every means of imagination - to the one where agency numbers, inspite of going down over the years, have still trumped the industry numbers. Bancassurance for SBI Life was always strong but has been fortified over the last five years and its growth is more or less the same as the slide in the corresponding banca numbers for HDFC Life. So while SBI Life mirrors the industry trend, both for agency and bancassurance - although vis-à-vis industry, it is slightly ahead in agency and overshoots in the banca- it is the online channel pattern which defies the industry by a long long way. While the online channel grew from $9 \%$ to $14 \%$ for the industry in the last five years, the corresponding numbers for SBI Life registered a degrowth from $2.5 \%$ to $1.44 \%$ (refer exhibit 3). So what does SBI do to get out of this dilemma? Put a control on bancassurance - even at the cost of business - and nurture a wobbling online channel instead while also preserving the agency? How to balance the distribution when the distribution mix seems too lopsided with the online channel missing out and bancassurance getting far too much prominence? We, would try to seek some solutions. 
Distribution problems at HDFC Life \& SBI Life: Probable Solutions

The most concrete and logical answers in our opinion lie in two reports - NIIT Technologies (2019) report and Cognizant Technologies (2014). The former emphasizes the need for a multi-distribution network with a suggestion that distribution mixes of the companies should be according to defined customer segments (Exhibit 4). Towards that end, the report has identified the channels which include the new introduced ones and mapped these channels with suitable customer segments (Exhibit 4). The latter, keeping in mind the fact that future buying in life insurance will be impacted by customer experiences across different industries, suggests that it is increasingly important to adopt a multi-distribution mechanism (Exhibit 5). Even at the risk of channel conflict, the report strongly advocates a multi distribution approach. To minimise such a risk, a unified and single view of the customer, the channel and the company, moving forward is proposed for approaching the future of distribution (FOD). The report further states that since the market has, and will, become much more diverse with new regulations taking place, the traditional channels need to innovate. As a result, perhaps in due course agency would be persisted with but can get transformed in an altogether different avatar, early signs of which have already started to happen through the incorporation of technology. Rounding off, on an interesting note, the report suggests that channels will - or have rather started to - influence products to a large extent and hence the NIIT Technologies (2019) Report's proposition of the 'channels for the segments', the type of insurance policy, in turn, will be decided by the choice of channel.

Exhibit 4: Balancing channel mix proposition (Future Ready: Multi-Channel Distribution in Life Insurance; NIIT Technologies)

Market Segment

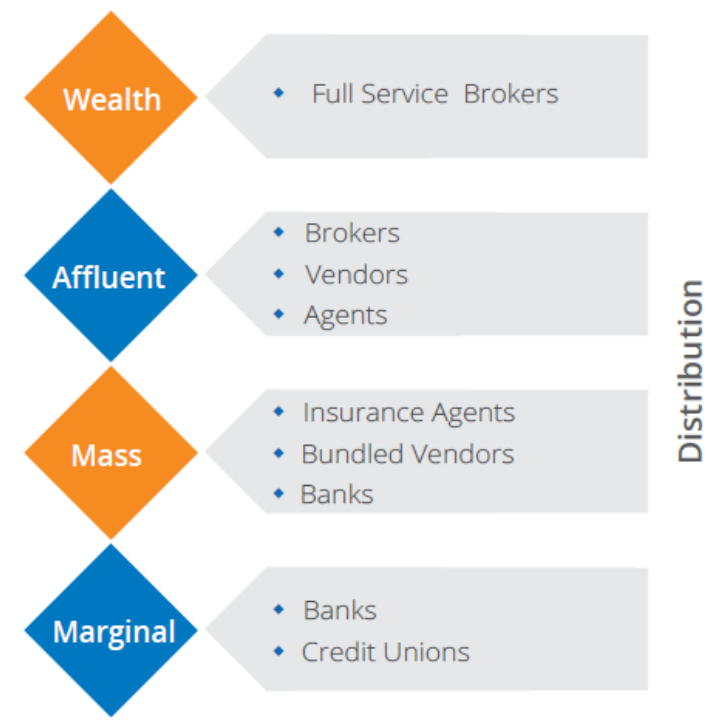

(Source: A 2019 report by NIIT Technologies on Future Ready: Multi-Channel Distribution in Life Insurance)

Exhibit 5: Balancing the distribution mix (Future of Distribution; Cognizant Technologies)

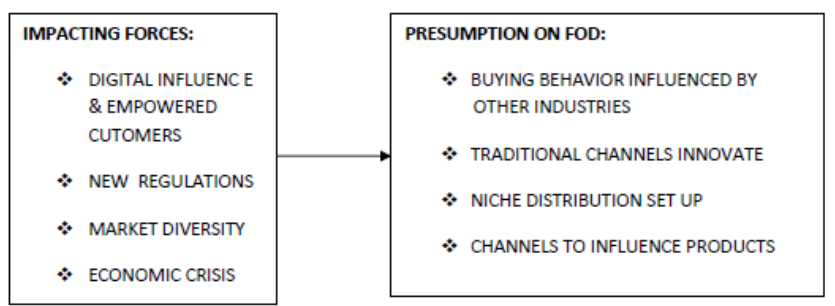

(Source: Cognizant Technologies Report - Preparing Life Insurers for Future of Distribution, 2014)

With the disruptions happening at a faster pace than ever before, we, the authors, are of the view that the two solutions proposed by the aforementioned reports are and need not be the 'be all and end all' of the distribution conundrum at HDFC Life \& SBI Life. HDFC Life ( Annual Report, 2018-19) has expressed vehemently the fact that it is open to embracing a multi channel mechanism so much so that it is working assiduously in expanding its outreach by offering the customer multiple touch-points. Balancing the distribution mix, though, still remains as elusive. SBI Life, on the other hand gives an impression of a company where adoption of technology in the distribution set up is still is a far cry and as such balancing of the distribution mix in its case seems a relatively tougher proposition. While nobody has seen the future and can at best anticipate, everything mentioned thus far is possible as is an altogether new distribution paradigm in the future. To that extent, even an integrated financial system (IFS) - although currently in existence but confined in presence - which combines the best features of all channels and financial services is a possibility. As stated, readying for the future of distribution and accordingly preparing for it should be the way out.

We are of the view that two solutions - NIIT Technologies Report, 2019 \& Cognizant Report, 2014 - are realistic and will work in the immediate present, creating a balanced channel mix with so many constraints remains challenging although possible. We say so in light of predictive data analytics together with technology available, meaning thereby, that predicting a balanced distribution structure is possible and the two companies in this study should resort to the same. Whatever be the manifestation of the same problem of distribution for these companies, the suggested solutions should provide some roadmap for easing out the distribution woes.

\section{CONCLUSION}

HDFC Life and SBI Life, two similar bank supported companies face the same ubiquitous problem of distribution, albeit manifested differently for each of them. In such a scenario designing the optimum distribution structure for them is a challenge. Agency, for all said and done cannot be dispensed with fully, even though it lags the much favored bancassurance. Similarly, any compromise on banacassurance is fraught with danger given its significance at present and the synergy it provides to the bank and the insurance company. So going with bancassurance, even if at a reduced pace, would mean adapting to the current times as also readying for the 
disruptions of the future. And lastly, the channel of much potential, the online channel - already seen as a channel of much substance - needs to be nurtured more. In a state of flux as the distribution finds itself in, designing a balanced mix is a question which currently has no fixed answers. HDFC Life and SBI Life have witnessed a vastly changed distribution landscape and it will be relevant to say that they put forth, in clear terms, their priorities of customers which could then be subsequently served through a proper channel mix. Anticipating further disruptions, multi-channel mix is good idea going forward notwithstanding channel conflicts, channel misalignment and so on and so forth. But then that does in no way solve the balancing woes. It could only be said that the approach these companies show towards the changing distribution landscape, will invariably dictate the way towards finding the 'all elusive balanced channel mix'.

\section{REFERENCES}

1. Baranoff, E.G., Baranoff, D. and Sager, T.W. (2000) 'Nonuniform regulatory treatment of broker distribution systems. An impact analysis for life insurers', Journal of Insurance Regulation 19: 94-118.

2. Barrese, James, Helen I. Doerpinghaus, and Jack M. Nelson, 1995. "Do Independent Agent Insurers Provide Superior Service? The Insurance Marketing Puzzle," Journal of Risk and Insurance, 62: 297-308.

3. Barrese, J., Nelson, J. M., 1992. Independent and Exclusive Agency Insurers: A Reexamination of the Cost Differential. Journal of Risk and Insurance 49, 375--397.

4. Benoist, G. (2002) 'Bancassurance: The new challenges', The Geneva Papers on Risk and Insurance 27 (3): 295-30

5. Berger, A.N., Cummins, J.D. and Weiss, M.A. (1997) 'The coexistence of multiple distribution systems for financial services: The case of property-liability insurance', Journal of Business 70: 515-546.

6. Chang, Pang Ru, Peng, Jin-Lung, and Fan, Chiang Ku, The Geneva Papers on Risk and Insurance. Issues and Practice, Vol. 36, No. 1 (January 2011), pp. 76-93

7. Chen, Su Mei \& Chang, Long Pao. (2010). Distribution channel strategy and efficiency performance of the life insurance industry in Taiwan. Journal of Financial Services Marketing. 15. 10.1057/fsm.2010.6.

8. Claessens S (2003) Benefits and costs of integrated financial services provision.. In: Litan RE, Herring $\mathrm{R}$ (eds) Brookings-wharton papers on financial services. Brookings Institution, Washington DC, pp 85-72

9. Crawford, Robert \& R. Klein, Benjamin \& A Alchian, Armen. (1978). Vertical Integration, Appropriable Rents, and the Competitive Contracting Process. Journal of Law and Economics. 21. 297-326. 10.1086/466922

10. Cummins, J. D., VanDerhei, J., 1979. A note on the relative efficiency of property-liability insurance distribution systems. Bell Journal of Economics and Management Science 10, 708--719.

11. Dzienziol, J., Eberhardt, M., Renz, A., Schackmann, J., 2002. Multi-Channel Pricing for Financial Services, in: Sprague, R.H. (Ed.), Proceedings of the 35th Hawaii International Conference on System Sciences, Los Alamitos, Calif. et al. IEEE Computer Society.

12. Easingwood, C., Storey, C., 1996. The Value of Multi-Channel Distribution Systems in the Financial Services Sector. The Services Industries Journal 16, 223--241.

13. Felgren S (1985) Banks as insurance agents: legal constraints and competitive advances. New England Econ Rev Sept/Oct:34-49
14. Finsinger, J., Schmidt, F.A., 1993. Gebundener versus ungebundener Vertrieb. Schmalenbachs Zeitschrift für betriebswirtschaftliche Forschung 45, 216--226.

15. HDFC(https://brandsite-static.hdfclife.com/media/documents lapps/Annual-Report\%20-\%20FY\%202018\%20\%E2\%80\%9 3\%202019.pdf

16. https://www.cognizant.com/InsightsWhitepapers/preparing-li fe-insurers-for-the-future-of-distribution-codex 1124.pdf

17. https://www.niit-tech.com/resource-library/white-papers/futu re-ready-multi-channel-distribution-life-insurance

18. https://www.sbilife.co.in/sites/SBILife/Annual-Report/FY201 8-19/pdf/SBI-Life-Annual-Report-2018-19.pdf

19. Joskow, P.( 1973 ) Cartels, competition and regulation in the property-liability insurance industry . Bell Journal of Economics and Management Science $4: 375$ - 427

20. Malone, T. W., J. Yates, and R. I. Benjamin, 1987. "Electronic Markets and Electronic Hierarchies," Communications of the ACM, 30: 484-497.

21. Marcel Corstjens and Peter Doyle, (1979), Channel Optimization in Complex Marketing Systems, Management Science, 25, (10), 1014-1025

22. Lakshmikutty, S. \& Bhaskar, S. (2005). Insurance distribution in India - A perspective. Journal of Insurance Chronicle, 5(6), pp 17-22.

23. Mayers, David and Clifford W. Smith Jr., 1981. "Contractual Provisions, Organizational Structure, and Conflict Control in Insurance Markets.” Journal of Business, 54: 407-434.

24. MehtaK.(2015)https://www.livemint.com/Money/vkrMCcZkl JiU69glMiNaL/The-need-to-build-deeper-insurance-distribu tion-landscape.html

25. Morgan, G. (1994), "Problems of integration and differentiation in the management of

26. 'Bancassurance'", The Service Industries Journal, Vol. 14 No. 2, pp. 53-169.

27. Posey, Lisa Lipowski and Abdullah Yavas, 1995. "A Search Model of Marketing Systems in Property-Liability Insurance. “ Journal of Risk and Insurance, 62: 666-689.

28. Query, J. Tim and Robert E. Hoyt, 2002. "Service Quality and Price in Private Passenger Automobile Insurance," Working Paper, University of Georgia, Athens, GA.

29. Regan, Laureen, 1997. "Vertical Integration in the Property-Liability Insurance Industry: A Transaction Cost Approach," Journal of Risk and Insurance, 64: 41-62.

30. Regan, Laureen (1999). "Expense Ratios Across Insurance Distribution Systems: An Analysis by Line of Business.” Risk Management and Insurance Review 2, (pages)

31. Regan, Laureen and Larry Tzeng (1999). "Vertical Integration and Ownership Form in the Property-Liability Insurance Industry." Journal of Risk and Insurance 66, 253-274.

32. Sarkar, M.B., B. Butler, and C. Steinfeld, 1995. "Intermediaries and Cybermediaries: A Continuing Role for Mediating Players in the Electronic Marketplace," Journal of Computer Mediated Communication, 1: 3.

33. Sinha, A. (2013). Emerging trends in distribution in the Life Insurance sector in India: A Study of a few Leading Players. Indian Journal of Marketing, 53-61

34. Sharma, R.P. \& Saxena, K. (2009). Life Insurance Marketing In India: Leveraging the strengths of Multi-Channel Distribution. Journal of Marketing trends, 8th Marketing trends congress, January 15-17, 2013

35. Tang, F.-F., \& Xing, X. (2001). Will the Growth of MultiChannel Retailing Diminish the Pricing Efficiency of the Web? Journal of Retailing, 77, 319-333. 
36. Todd J, Murray M (1988) Banks in insurance: increase or reduce competition. J Insur Regul 6:518-537

37. Tone, K. and Sahoo, B.K. (2005), "Evaluating cost efficiency and returns to scale in the LifeInsurance Corporation of India using data envelopment analysis", Socio-Economic Planning Sciences, Vol. 39, pp. 261-85.

38. Trembly, Ara C., 2001, "Why the insurance industry has failed in the online distribution channel," National Underwriter (Life \& Health Services edition), 105: 19-21.

39. Webb. K.L., 2002. Managing channels of distribution in the age of electronic commerce. Industrial Marketing Management 31, 95--102.

40. Williamson, O. (1981). The economics of organization: The transaction cost approach. The American Journal of Sociology, 87(3), 548-577 